(c) American Dairy Science Association, 2005.

\title{
Effects of Dexamethasone and Growth Hormone Treatment on Hepatic Gluconeogenic Enzymes in Calves
}

\author{
H. M. Hammon, ${ }^{*, 1}$ C. Philipona, ${ }^{1}$ Y. Zbinden, ${ }^{1}$ J. W. Blum, ${ }^{1}$ and S. S. Donkin ${ }^{2}$ \\ ${ }^{1}$ Division of Nutrition and Physiology, Institute of Animal Genetics, Nutrition and Housing, \\ Vetsuisse Faculty, University of Berne, $\mathrm{CH}-3012$ Berne, Switzerland \\ ${ }^{2}$ Department of Animal Science, Purdue University, West Lafayette, IN 47907
}

\section{ABSTRACT}

The hypothesis was tested that dexamethasone (DX) and bovine somatotropin (bST) alter expression or activity of gluconeogenic enzymes in neonatal calves. Holstein dairy calves $(n=24)$ were randomly divided in 4 groups and were treated with saline (control group), with DX at $30 \mu \mathrm{g} / \mathrm{kg}$ body weight per d (CDX), with 500 mg of sustained-release recombinant bST every $14 \mathrm{~d}$ (CbST), and with the combination of DX and bST from d 3 through 42 of life (CbSTDX). Plasma glucose and insulin concentrations were elevated throughout the study in CbSTDX, and insulin concentrations were elevated in CDX from $\mathrm{d} 7$ to 28 . Treatment with DX and the combination of DX and bST increased plasma glucagon concentrations from d 14 to 42 , but decreased plasma cortisol concentrations on d 7 and 14 when compared with control calves. In liver, phosphoenolpyruvate carboxykinase (PEPCK) mRNA levels were reduced in CDX and CbSTDX when compared with control calves or CbST. The activity of PEPCK on d 14 was higher in CbSTDX compared with control calves. Pyruvate carboxylase mRNA levels were decreased on $\mathrm{d} 7$ in CDX and CbSTDX. Pyruvate carboxylase activities on d 14 and 28 were lower in CDX and CbSTDX than in control calves or CbST. These data indicate an age-dependent response to DX for blood metabolites, expression and activities of hepatic PEPCK and pyruvate carboxylase, and for effects of bST, suggesting that glucocorticoid status is important.

(Key words: glucocorticoid, bovine somatotropin, gluconeogenesis, calf)

Abbreviation key: CbST = calves treated with bST, CbSTDX = calves treated with dexamethasone and bST, DX = dexamethasone, $\mathbf{C D X}=$ calves treated with

Received October 4, 2004.

Accepted January 18, 2005.

Corresponding author: H. M. Hammon; e-mail: hammon@ fbn-dummerstorf.de.

*Present address: Research Institute for the Biology of Farm Animals (FBN), Nutrition Physiology (Oskar Kellner Institute), WilhelmStahl-Allee 2, 18196 Dummerstorf, Germany. dexamethasone, $\mathbf{P C}=$ pyruvate carboxylase, $\mathbf{P E P C K}=$ phosphoenolpyruvate carboxykinase.

\section{INTRODUCTION}

Glycogenolysis and gluconeogenesis are important for neonatal glucose homeostasis because lactose intake with colostrum and milk fails to meet glucose demands during early life (Girard et al., 1992; Liggins, 1994). Induction of these processes at birth in calves is especially critical because calves are born in a hypoglycemic state (Hammon and Blum, 1998b). Plasma cortisol concentrations increase sharply in the bovine fetus and remain elevated during the neonatal period (Liggins, 1994; Hammon and Blum, 1998b). Cortisol enhances glucose production and glycogen storage around birth in humans and in precocious species such as ruminants (Liggins, 1994; Fowden, 1997). Conversely, cortisol may increase plasma glucose concentrations through depressed glucose utilization, induction of insulin resistance, or both (McDowell, 1983; Wajchenberg et al., 1984; Brockman and Laarveld, 1986).

The somatotropic axis is the main endocrine system regulating postnatal growth in mammals, but prenatal growth is essentially independent of growth hormone (Breier et al., 2000). Administration of bST exerts effects on glucose metabolism partly by antagonizing glucose responses to insulin in liver and peripheral tissues (Etherton and Bauman, 1998; Breier et al., 2000). However, gene expression and binding capacity of hepatic growth hormone receptors are low at and shortly after birth and only slowly increase during the first weeks of life (Breier et al., 2000; Hammon et al., 2003b), as a consequence growth-stimulating effects after bST treatment in young calves are small or absent (Hammon et al., 2003b). Somatotropin stimulates hepatic gluconeogenesis in lactating dairy cows (McDowell, 1983; Etherton and Bauman, 1998), but because of the limited number of hepatic growth hormone receptors, it is unclear if bST has this same effect in young calves.

Phosphoenolpyruvate carboxykinase (PEPCK; EC 4.1.1.32) and pyruvate carboxylase (PC; EC 6.4.1.1) are rate-limiting enzymes for gluconeogenesis in liver 
(Rognstad, 1979; Girard et al., 1992; Donkin, 1999) and are regulated by glucocorticoids (Pilkis and Granner, 1992; Hanson and Reshef, 1997; Jitrapakdee and Wallace; 1999). Both enzymes are active in the bovine fetus (Prior and Scott, 1977). Fast hepatic gluconeogenic rates, such as during the postpartum period of lactating cows, are associated with elevated expression of PEPCK and PC (Greenfield et al., 2000; Agca et al., 2002).

The present study was carried out to clarify the influence of dexamethasone (DX) and bST treatment on glucose status in young calves through enhanced expression of key genes in hepatic glucose synthesis. The objective of the study presented here was to investigate the effects of DX and bST on hepatic abundance of PEPCK and PC mRNA and activity, enhanced levels of glucoregulatory hormones, blood glucose, and hepatic glycogen content in calves.

\section{MATERIALS AND METHODS}

\section{Animals, Husbandry, Feeding, and Experimental Procedures}

All animal handling procedures were approved by the Purdue Animal Care and Use Committee. Twentyfour male Holstein calves, aged 1 to $2 \mathrm{~d}$, were purchased from a single large commercial dairy farm and transported to the Purdue University Dairy Research and Education Center. Calves were born spontaneously, separated from their dams at birth, fed colostrum, and housed individually. Calves were weighed upon receipt, blocked by initial BW, and randomly assigned within block to one of 4 treatment groups ( $n=6$ per group). Treatments were initiated on $\mathrm{d} 3$ of life. The CDX group included calves administered DX subcutaneously (Azium; Schering-Plough, Terre Haute, IN) at $30 \mu \mathrm{g} /$ $\mathrm{kg}$ BW per d. The CbST group included calves administered growth hormone at $500 \mathrm{mg}$ recombinant bST (Posilac; Monsanto, St. Louis, MO) subcutaneously at 14-d intervals. A CbSTDX group included calves administered the combination of DX and bST. And the fourth group of calves was administered saline, which was the control group. The saline was delivered in the same amounts as for DX injected subcutaneously. Treatments continued up to $42 \mathrm{~d}$ of age. This dose of DX was chosen according to previous studies with neonatal calves (Hammon et al., 2003a).

Calves were fed a milk replacer diet (Milk Specialties Company, Dundee, IL), which contained $29 \%$ CP, $15 \%$ crude fat, and $<0.15 \%$ crude fiber at a rate of $2 \%$ of BW on an air-dry milk replacer basis. Ingredients were dried whey, dried whey protein concentrate, animal and vegetable fat, lecithin, dried skimmed milk, and dried milk protein. Milk replacer was diluted with warm wa- ter to $15 \%$ solids and was fed in buckets twice daily at 0700 and $1600 \mathrm{~h}$. Calves were weighed weekly, and amounts fed were adjusted according to BW. Fresh water was available at all times. Calves that failed to voluntarily consume milk replacer within 45 min were fed their scheduled allotment of milk replacer via stomach tube.

All calves were injected i.m. with ampicillin twice daily (Polyflex; Wyeth, Fort Dodge Animal Health, Overland Park, KA) at $1.5 \mathrm{mg} / \mathrm{kg}$ BW and $1500 \mathrm{U} / \mathrm{kg}$ BW penicillin G procaine daily (Penicillin G Procaine; G.C. Hanford, Syracuse, NY) upon receipt for the next $2 \mathrm{~d}$ as protection against pathogens. The health status was evaluated daily based on the following clinical traits: rectal temperature, heart rate, respiratory rate, behavior, nasal discharge, respiratory sounds, appetite, fecal consistency, and navel inspection. Any calves with symptoms of respiratory or gastrointestinal infections were treated for recovery by the Purdue University Veterinary Clinical Sciences. All animal handling and use protocols were reviewed and approved by the Purdue Animal Care and Use Committee.

\section{Blood Sampling and Analyses}

Blood was collected from the jugular vein with evacuated tubes at 4 to $5 \mathrm{~h}$ after feeding on $\mathrm{d} 3,7,14,28$, and 42 of life. Tubes were kept on crushed ice until centrifuged at $550 \times \mathrm{g}$ for $15 \mathrm{~min}$. Supernatants were aliquoted and stored at $-20^{\circ} \mathrm{C}$. Blood collection tubes containing dipotassium-EDTA (1.8 g/L of blood) were used for samples analyzed for plasma glucose, insulin, glucagon, and cortisol. Plasma glucose concentrations were measured by the glucose oxidase method using a kit (No. 115; Sigma Diagnostics, St. Louis, MO). Plasma concentrations of insulin, glucagon, and cortisol were measured by radioimmunoassays as described previously (Hammon and Blum, 1998b).

\section{Analyses in Liver}

Liver biopsy samples (about $500 \mathrm{mg}$ ) were obtained at 3 to $4 \mathrm{~h}$ after feed intake on d 7, 14, 28, and 42 of life for analysis of PC and cytosolic PEPCK mRNA levels, activities of PC and total PEPCK (cytosolic and mitochondrial), and glycogen content. Biopsy technique was adapted from Greenfield et al. (2000). Calves were restrained using a small animal squeeze chute and tilt table combination and were placed on their left side. The area above the 11th and 12th intercostal space on a line from the hip joint to the elbow was clipped, scrubbed with Betadine (Purdue Pharma L.P., Stamford, CT), and swabbed with $70 \%$ ethanol. Ten milliliters of lidocaine ( $2 \%$ lidocaine hydrochloride) was in- 
jected subcutaneously. Liver biopsy samples were obtained pericutaneously. Samples were rinsed in saline and transferred to a fresh tube containing a guanidinium thiocyanate solution [ $4 M$ guanidinium thiocyanate, $25 \mathrm{mM}$ sodium citrate (pH 7.4), 0.5\% sarkosyl, and $0.1 M \beta$-mercaptoethanol] and frozen in liquid nitrogen (for mRNA measurements) or rinsed in saline and directly frozen in liquid nitrogen. All samples were stored at $-80^{\circ} \mathrm{C}$ until analysis.

RNA isolation and Northern blotting. Total RNA was extracted from biopsy samples, and $20 \mu \mathrm{g}$ was separated by electrophoresis through a $1 \%$ agarose gel, transferred to Genescreen membrane (NEN Life Science Products, Boston, MA), and prehybridized as described by Donkin et al. (1996). The cDNA probes of PC and PEPCK were described by Agca et al. (2002) and Greenfield et al. (2000). The ${ }^{32} \mathrm{P}$-labeled cDNA probes were prepared using ${ }^{32} \mathrm{P}[\mathrm{dCTP}]$ and the readyto-go DNA labeling beads dCTP random oligonucleotide priming kit (Pharmacia, Piscataway, NY) to a specific activity of approximately $10^{9} \mathrm{cpm} / \mu \mathrm{g}$ of DNA. Membranes were probed sequentially for PC, PEPCK, and 18S rRNA. Membranes were exposed to Kodak X-Omat film for 1 to $3 \mathrm{~d}$ at $-80^{\circ} \mathrm{C}$. The removal of labeled probes from membranes was verified using a Geiger counter. Abundance of mRNA for each transcript was quantified from digital scans of autoradiographic images using Kodak Digital Science 1-D Image Analysis software (Eastman Kodak Co., Rochester, NY). Differences in loading and transfer of RNA among samples were adjusted by normalizing the PC and PEPCK data to the overall mean intensity of the $18 \mathrm{~S}$ signal. A pooled RNA sample was used for correction between blots. The size of the transcript was determined by the migration distance relative to RNA standards. Northern blots of PC and PEPCK resulted in one band at $4.2 \mathrm{~kb}$ for $\mathrm{PC}$ and $2.8 \mathrm{~kb}$ for PEPCK and agreed with Greenfield et al. (2000).

Measurement of enzyme activities. Measurements of hepatic PEPCK and PC activities followed Greenfield et al. (2000) and Agca et al. (2002). Liver tissue was homogenized in $(\mathrm{wt} / \mathrm{vol}=1: 3)$ buffer containing cold 0.1 $M$ sucrose, $50 \mathrm{~m} M$ potassium phosphate ( $\mathrm{pH} 7.4$ ), and $0.25 \mathrm{~m} M$ EDTA (pH 7.4). Samples were sonicated for $10 \mathrm{~s}$ to disrupt mitochondria. The homogenates were kept on ice at all times. The PEPCK activities were determined in cell homogenates by measuring the carboxylation of phosphoenolpyruvate to oxaloacetate using $\mathrm{NaH}^{14} \mathrm{CO}_{3}$ (Ballard and Hanson, 1967) with the addition of $\mathrm{NADH}$ and malate dehydrogenase to ensure the conversion of the reaction product, oxaloacetate, to malate (Atkin et al., 1979). Activities of PC were assayed in the crude homogenate by $\mathrm{NaH}^{14} \mathrm{CO}_{3}$ incorpora- tion into oxaloacetate and citrate in the presence of pyruvate (Atkin et al., 1979).

Measurement of glycogen content. Hepatic glycogen concentrations were converted to glucose by amyloglucosidase (EC 3.2.1.33), as described by Roehrig and Allred (1974). Glucose concentrations were measured as described previously. The protein concentration in liver was determined using a kit (BCA Protein Assay Reagent; Pierce, Rockford, IL).

\section{Statistical Procedures}

Data were expressed as means $( \pm$ SEM). Data were evaluated using the RANDOM and REPEATED methods of the MIXED procedure (SAS, 1995). Dexamethasone and bST treatment and time were used as fixed effects, and the individual calves were used as random effects. Treatment and time effects were localized by Bonferroni $t$-test $(P<0.05)$. Because of heteroscedasticity, the data of plasma concentrations and mRNA levels were transformed to log values prior to analysis and reported values reflect the untransformed means.

The PROC CORR procedure of the SAS program (SAS, 1995) was used to calculate correlations between abundance of mRNA, enzyme activities, glycogen content, and plasma concentrations.

\section{RESULTS}

\section{Feed Intake, BW, and Health Status}

Data for BW and feed intake were presented elsewhere (Hammon et al., 2003b). Two calves treated with DX and bST plus DX, respectively, were removed from the study after d 28 because of health problems. All other calves were healthy through the end of the study.

\section{Blood Plasma Concentrations of Glucose, Insulin, Glucagon, and Cortisol}

Plasma glucose concentrations were similar for all calves at the beginning of the experiment, and plasma glucose concentrations decreased $(P<0.05)$ in the control calves and in CDX from d 3 to 14 (Figure 1). Plasma glucose concentrations were highest $(P<0.05)$ in CbSTDX throughout the study. On d 42, glucose concentrations in CDX tended to be depressed relative to control calves $(P<0.1)$ and were lower than values for $\operatorname{CbST}(P<0.05)$.

Plasma insulin concentrations increased $(P<0.01)$ in CDX from d 3 to 28 and in CbSTDX from d 7 to 42 (Figure 2). Insulin concentrations were highest $(P<$ 0.05) in CbSTDX throughout the whole study and were higher $(P<0.05)$ in CDX than in control calves from $d$ 


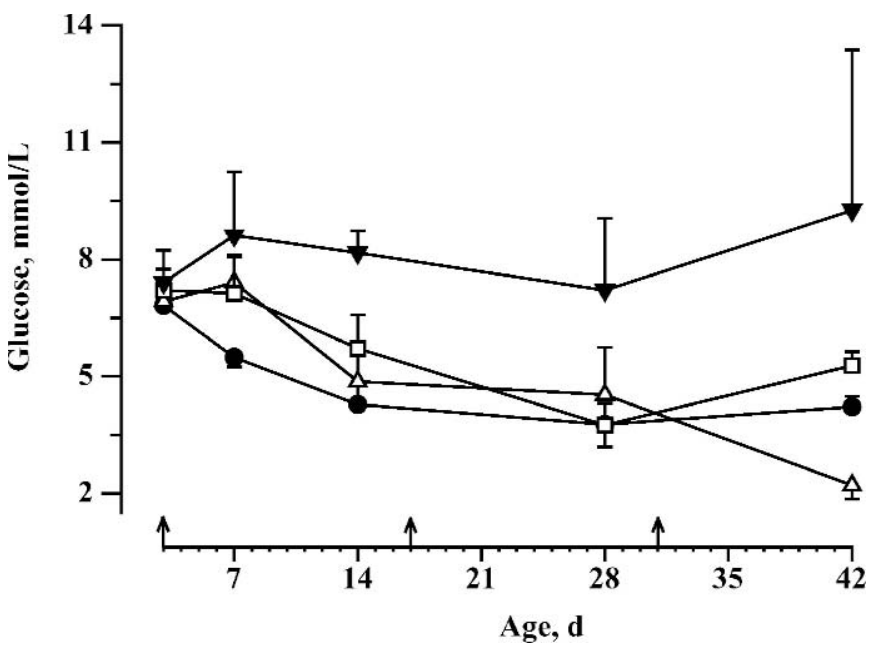

Figure 1. Plasma glucose concentrations on d 3, 7, 14, 28, and 42 of life in control calves (-), calves treated with dexamethasone (DX) (30 $\mu \mathrm{g} / \mathrm{kg}$ BW per d; CDX; $\triangle$ ), calves treated with sustained-release recombinant bST (500 mg/14 d; CbST; $\square$ ), and calves treated with DX and bST (CbSTDX; $\boldsymbol{\nabla}$ ) in the same amounts as CDX and CbST. Arrows mark time of bST treatment.

7 to 28 . Insulin concentrations were higher $(P<0.05)$ in CDX than in CbST on d 28.

Plasma glucagon concentrations did not change with age (Figure 3), but concentrations were elevated $(P<$ 0.05) for CDX and CbSTDX compared with control calves from d 14 to 42 . Glucagon concentrations at the end of the experiment $(\mathrm{d} 42)$ were lower $(P<0.05)$ in CbST than in CDX and CbSTDX.

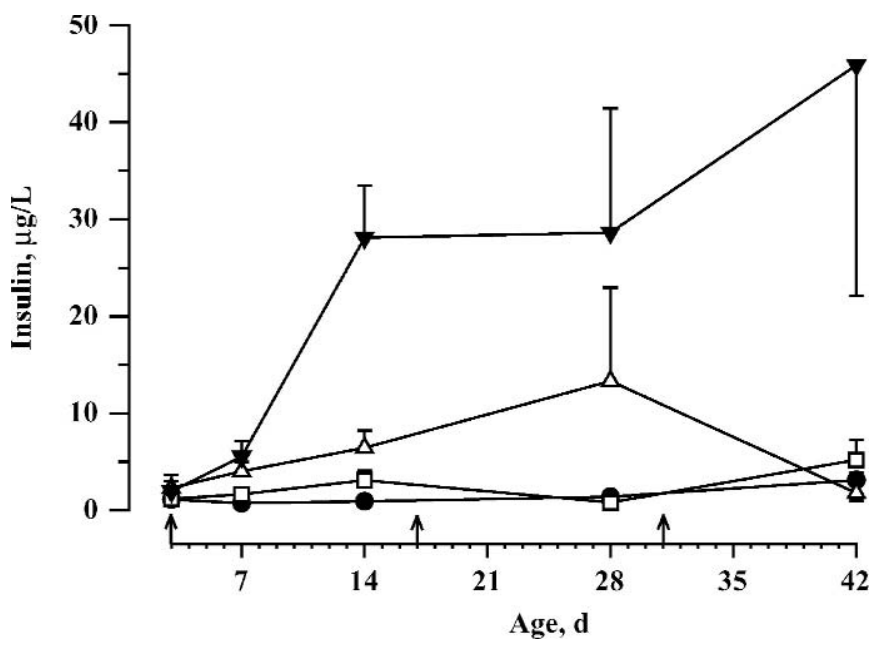

Figure 2. Plasma insulin concentrations on d $3,7,14,28$, and 42 of life in control calves $(\bullet)$, calves treated with dexamethasone (DX) (CDX; $30 \mu \mathrm{g} / \mathrm{kg}$ BW per $\mathrm{d} ; \triangle$ ), calves treated with sustained-release recombinant bST (500 mg/14 d; CbST; $\square$ ), and calves treated with DX and bST (CbSTDX; $\boldsymbol{\nabla}$ ) in the same amounts as CDX and CbST. Arrows mark time of bST treatment.

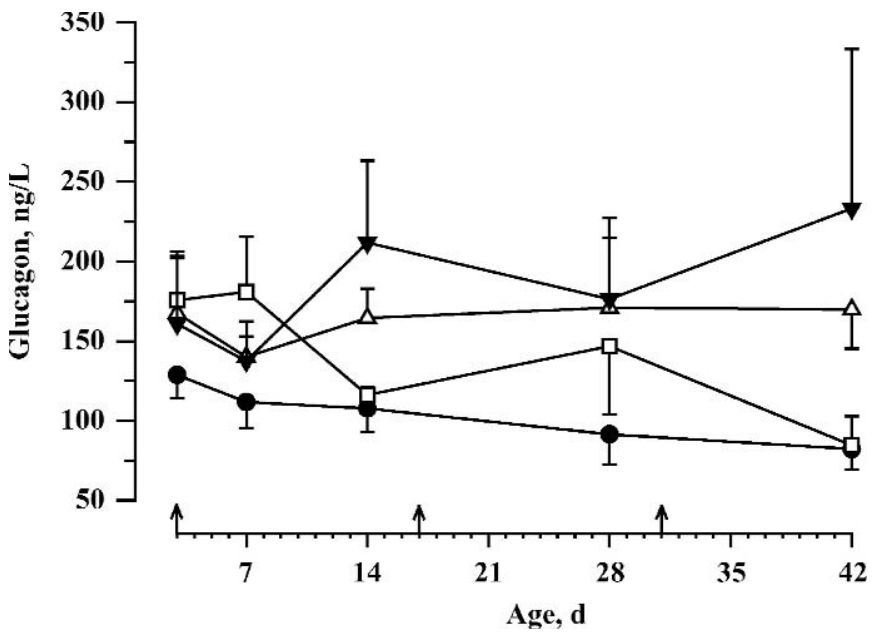

Figure 3. Plasma glucagon concentrations on d 3, 7, 14, 28, and 42 of life in control calves ( ) calves treated with dexamethasone (DX) $(30 \mu \mathrm{g} / \mathrm{kg}$ BW per d; CDX; $\triangle)$, calves treated with sustainedrelease recombinant bST (500 mg/14 d; CbST; $\square$ ), and calves treated with DX and bST (CbSTDX; $\boldsymbol{\nabla}$ ) in the same amounts as CDX and CbST. Arrows mark time of bST treatment.

Plasma cortisol concentrations decreased $(P<0.05)$ in control calves from $\mathrm{d} 3$ to 28 , decreased in CDX and CbSTDX from $\mathrm{d} 3$ to 7 , and increased in CbST from d 3 to 7, but decreased onward from d 7 to 42 (Figure 4). Cortisol concentrations were higher $(P<0.05)$ in control calves and CbST than in CDX and CbSTDX on $\mathrm{d} 7$ and

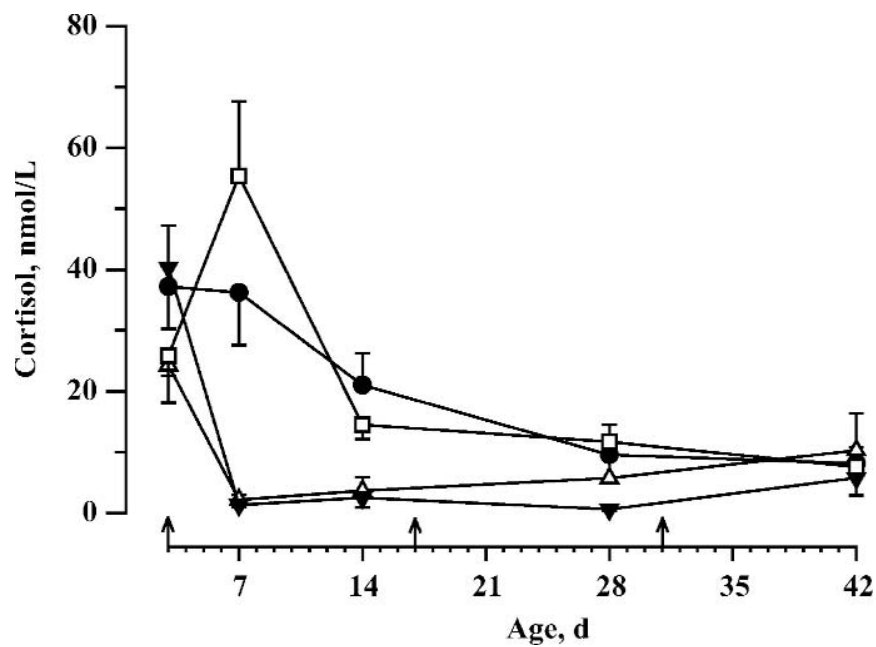

Figure 4. Plasma cortisol concentrations on d 3, 7, 14, 28, and 42 of life in control calves (-), calves treated with dexamethasone (DX) (30 $\mu \mathrm{g} / \mathrm{kg}$ BW per d; CDX; $\triangle$ ), calves treated with sustained-release recombinant bST (500 mg/14 d; CbST; $\square$ ), and calves treated with DX and bST (CbSTDX; $\boldsymbol{\nabla}$ ) in the same amounts as CDX and CbST. Arrows mark time of bST treatment. 
14 and were higher $(P<0.05)$ in CbST than in control calves on $\mathrm{d} 7$.

\section{Hepatic Gluconeogenic Enzyme mRNA Levels and Activities and Concentrations of Glycogen and Protein}

Abundance of cytosolic PEPCK mRNA increased ( $P$ $<0.05$ ) in control calves and CbSTDX from d 7 to 42 , increased in CDX from d 7 to 14 and from d 28 to 42 , and increased in CbST from d 7 to 14 (Figure 5A). The PEPCK mRNA was lower $(P<0.05)$ in CDX and CbSTDX than in control calves and CbST throughout the study.

Abundance of PC mRNA increased $(P<0.05)$ in CDX from d 7 to 28 and in CbSTDX from d 7 to 42 (Figure 5B). Levels of PC mRNA were lower $(P<0.05)$ on $d 7$ in CDX and CbSTDX than in control calves and CbST and tended to be lower $(P<0.1)$ on $\mathrm{d} 14$ in CbSTDX than in control calves.

Activities of PEPCK increased $(P<0.05)$ in CbST from $\mathrm{d} 7$ to 14 and increased $(P<0.05)$ in CbSTDX from $\mathrm{d} 7$ to 14 but then decreased $(P<0.05)$ thereafter to $\mathrm{d}$ 42 (Figure 6A). Activities of PEPCK were higher $(P<$ 0.05) in CbSTDX than in control calves and CDX on d 14.

Activities of PC decreased $(P<0.05)$ in control calves from $\mathrm{d} 7$ to 42 and decreased in CDX and CbSTDX from $\mathrm{d} 7$ to 28 but increased in both CDX and CbSTDX to d 42 (Figure 6B). On d 7, PC activities tended to be higher $(P<0.1)$ in control calves than in CDX. On $d 14$ and 28, PC activities were lower $(P<0.05)$ in CDX and CbSTDX than in control calves and CbST.

Hepatic glycogen content decreased $(P<0.05)$ in control calves and CDX from d 7 to 14, but increased in control calves $(P<0.05)$ from d 14 to 28 and decreased $(P<0.05)$ in CbSTDX from $d 7$ to 42 (Figure 7). The glycogen content was higher $(P<0.05)$ in control calves than in CbST on d 7 and 28 and was higher $(P<0.05)$ in control calves than in CDX and CbSTDX on d 42.

Hepatic protein concentrations were not influenced by time or treatment. Mean protein concentration was $70.9 \pm 9.5 \mu \mathrm{g} / \mathrm{mg}$ wt.

Effects of DX and bST treatment on plasma concentrations of glucose and hormones, enzyme gene expression and activities, and glycogen content in liver are summarized in Table 1.

\section{Correlations}

Enzyme activities of PC were related to PC mRNA levels $(\mathrm{r}=0.29 ; P<0.01)$, but PEPCK activities were not related to cytosolic PEPCK mRNA levels. Plasma glucose concentrations were negatively related to
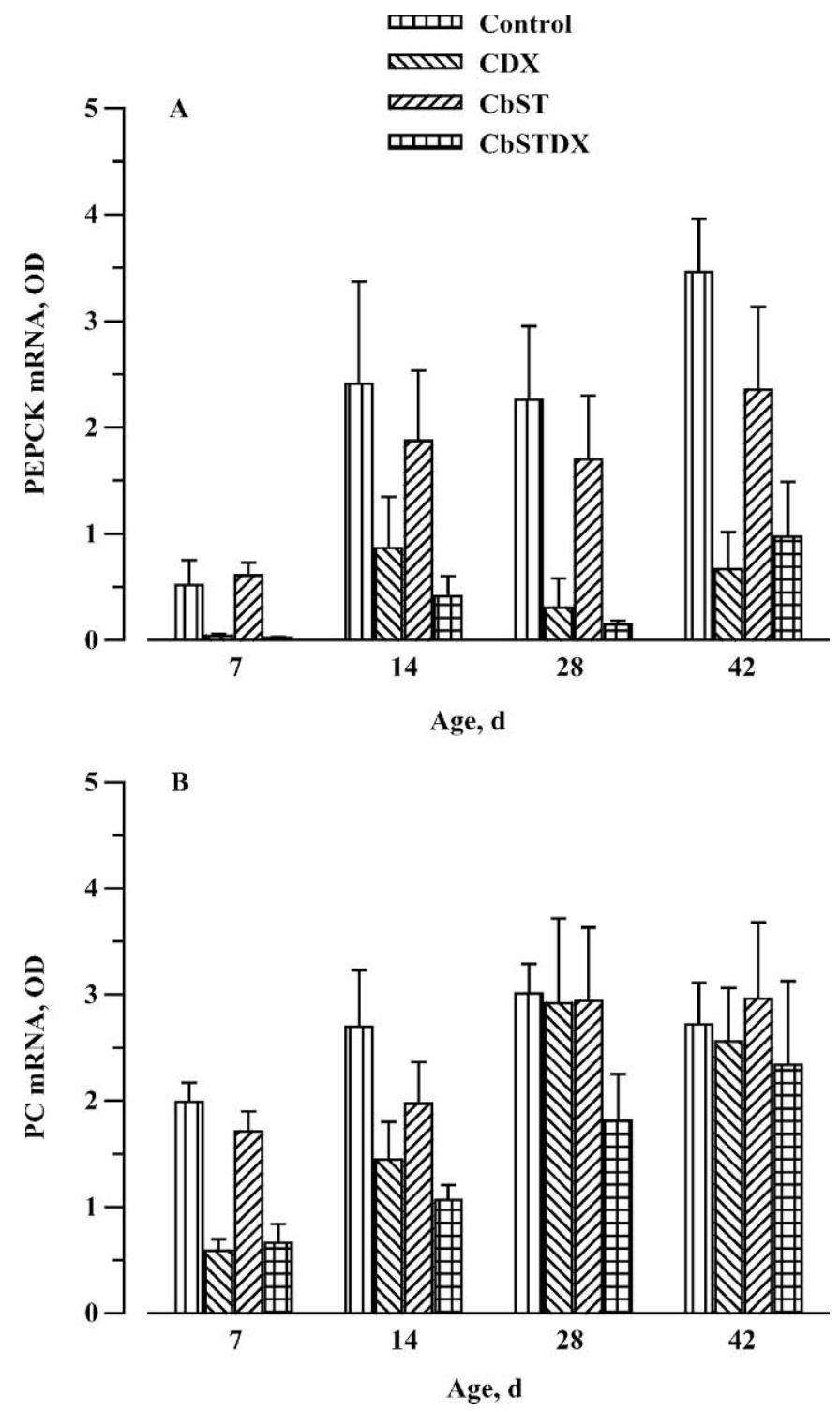

Figure 5. Abundance of hepatic cytosolic phosphoenolpyruvate carboxylinase (PEPCK) (A) and pyruvate carboxylase (PC) (B) mRNA on $\mathrm{d} 7,14,28$, and 42 of life in control calves, calves treated with dexamethasone (DX) $(30 \mu \mathrm{g} / \mathrm{kg} \mathrm{BW}$ per d; CDX), calves treated with sustained-release recombinant bST ( $500 \mathrm{mg} / 14 \mathrm{~d}$; CbST), and calves treated with DX and bST (CbSTDX) in the same amounts as CDX and CbST. OD = Optical density.

mRNA levels of PC and PEPCK $(\mathrm{r}=-0.34$ and -0.26 ; $P<0.01$, respectively) but were positively related to PEPCK activities $(\mathrm{r}=0.35 ; P<0.01)$ and plasma insulin concentrations $(\mathrm{r}=0.31 ; P<0.01)$. Plasma insulin concentrations were negatively related to mRNA levels of $\mathrm{PC}$ and PEPCK $(\mathrm{r}=-0.28$ and $-0.22 ; P<0.01$ and $P<$ $0.05)$ and $\mathrm{PC}$ activities $(\mathrm{r}=-0.25 ; P<0.05)$. Plasma glucagon concentrations were negatively related to mRNA levels of PEPCK $(\mathrm{r}=-0.24 ; P<0.05)$ and hepatic 

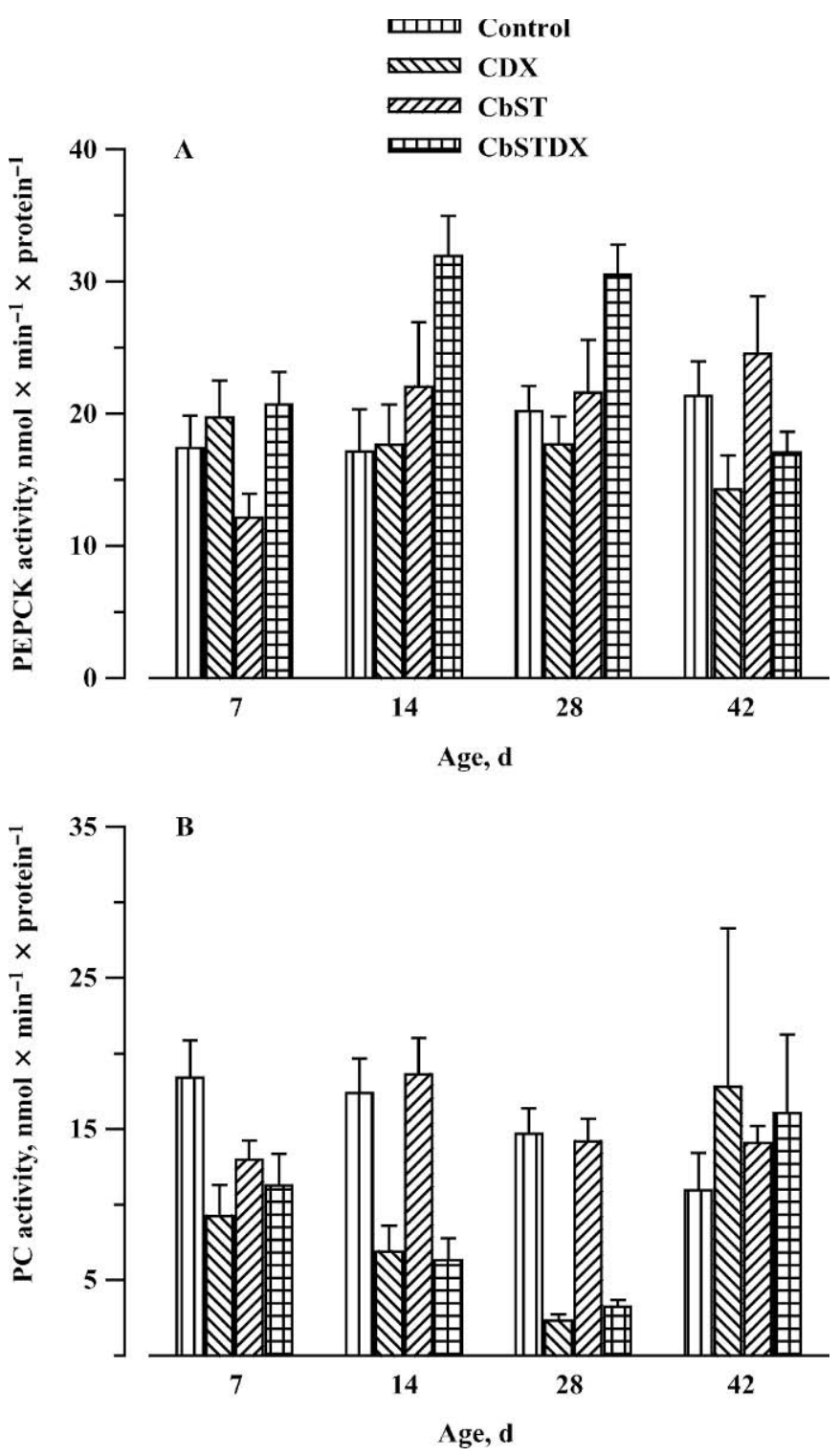

Figure 6. Enzyme activities of hepatic phosphoenolpyruvate carboxylinase (PEPCK) (A) and pyruvate carboxylase (PC) (B) on d 7, 14,28 , and 42 of life in control calves, calves treated with dexamethasone (DX) (30 $\mu \mathrm{g} / \mathrm{kg}$ BW per d; CDX), calves treated with sustainedrelease recombinant bST (500 mg/14 d; CbST), and calves treated with DX and bST (CbSTDX) in the same amounts as CDX and CbST.

glycogen concentration $(\mathrm{r}=-0.45 ; P<0.01)$ but were positively related to plasma concentrations of glucose and insulin ( $\mathrm{r}=0.36$ and $0.39 ; P<0.01$, respectively).

\section{DISCUSSION}

The aim of the present study was to clarify the role of DX and bST treatment on glucoregulatory hormones and on enzymes involved in hepatic gluconeogenesis in

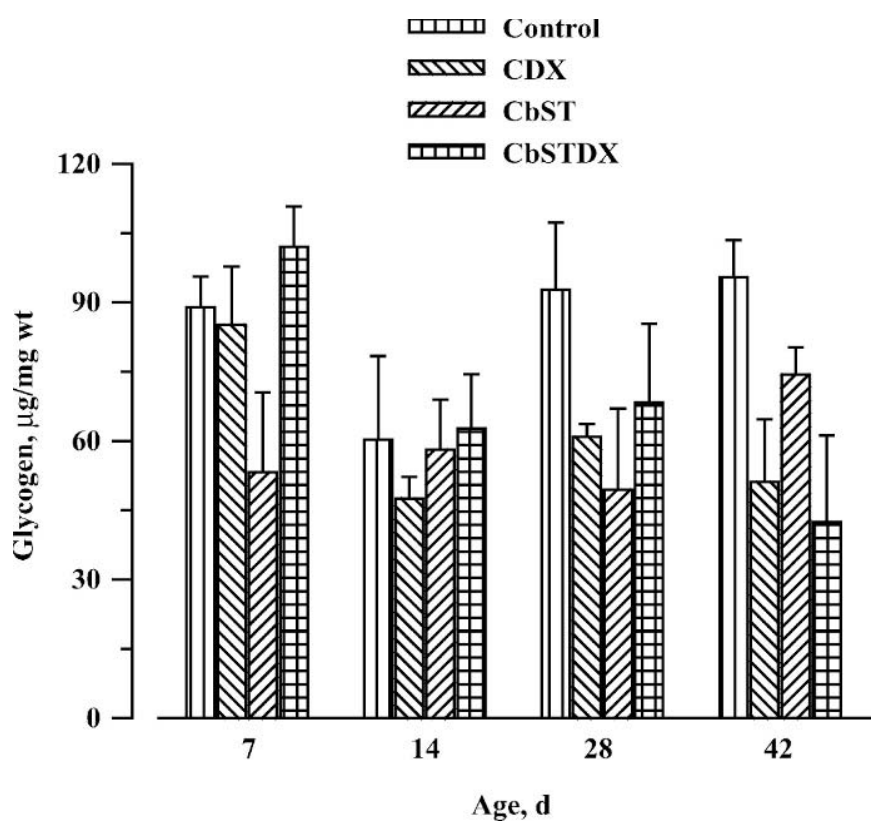

Figure 7. Hepatic glycogen content on d 7, 14, 28, and 42 of life in control calves, calves treated with dexamethasone (DX) $(30 \mu \mathrm{g} / \mathrm{kg}$ BW per d; CDX), calves treated with sustained-release recombinant bST (500 mg/14 d; CbST), and calves treated with DX and bST (CbSTDX) in the same amounts as CDX and CbST.

the developing calf. Therefore, we investigated mRNA profiles and activities of $\mathrm{PEPCK}$ and $\mathrm{PC}, 2$ rate-limiting enzymes for gluconeogenesis (Rognstad, 1979; Girard et al., 1992; Donkin, 1999). Whereas effects of bST treatment on glucose homeostasis were low, DX treatment and even more so the combined DX plus bST treatment indicated marked changes in glucose homoeostasis in calves during the neonatal and postnatal period.

In the absence of exogenous hormonal treatment (control), the hepatic activity of PC decreased with age. In ruminants, fetal liver contains PC enzyme activity that is detected by $160 \mathrm{~d}$ of gestation (Wallace, 1984), and the activity of $\mathrm{PC}$ is responsive to the nutritional status (Filsell et al., 1969). Expression of PC mRNA is related to enzyme activities in 5-d-old calves (Hammon et al., 2003a), and gluconeogenesis from lactate is decreased with age in hepatocytes isolated from developing calves (Donkin and Armentano, 1995). In contrast, cytosolic PEPCK mRNA levels increased with time in control calves, but PEPCK enzyme activities remained unchanged. Activity of PEPCK is not observed in rat liver before birth, but increases immediately after birth (Hanson and Reshef, 1997). Furthermore, PEPCK gene expression in milk-fed calves used in this experiment was not reflected by PEPCK enzyme activities. Reasons for these findings are not apparent because expression and activity are related in mature 
Table 1. Summary of the effects of dexamethasone (DX) and bST treatment on plasma concentrations and hepatic parameters in young calves. $^{1}$

\begin{tabular}{llll}
\hline & \multicolumn{3}{c}{$\begin{array}{c}\text { Treatment effect compared } \\
\text { with control calves }\end{array}$} \\
\cline { 2 - 4 } Item & $\mathrm{DX}^{1}$ & bST & $\begin{array}{l}\text { bST } \\
\text { plus DX }\end{array}$ \\
\hline Plasma concentrations & & & \\
Glucose & $---\downarrow$ & ---- & $\uparrow \uparrow \uparrow \uparrow$ \\
Insulin & $\uparrow \uparrow \uparrow-$ & ---- & $\uparrow \uparrow \uparrow \uparrow$ \\
Glucagon & $-\uparrow \uparrow \uparrow$ & ---- & $-\uparrow \uparrow \uparrow$ \\
Cortisol & $\downarrow \downarrow--$ & $\uparrow---$ & $\downarrow \downarrow--$ \\
PEPCK, Liver & & & \\
mRNA & $\downarrow \downarrow \downarrow \downarrow$ & ---- & $\downarrow \downarrow \downarrow \downarrow$ \\
Activity & ---- & ---- & $-\uparrow--$ \\
PC, Liver & & & \\
mRNA & $\downarrow---$ & ---- & $\downarrow \downarrow--$ \\
Activity & $\downarrow \downarrow \downarrow-$ & ---- & $-\downarrow \downarrow-$ \\
Glycogen, Liver & $---\downarrow$ & $-\downarrow-\downarrow-$ & $---\downarrow$ \\
\hline
\end{tabular}

$1 \uparrow=$ Increase/stimulation; $\downarrow=$ decrease/inhibition; - = no effect; the 4 characters in each field stand for effects on $\mathrm{d} 7,14,28$, and 42 , respectively.

${ }^{2} \mathrm{PEPCK}=$ Phosphoenolpyruvate carboxylinase.

${ }^{3} \mathrm{PC}=$ Pyruvate carboxylase.

cows (Agca et al., 2002), but a poor relationship for PEPCK mRNA and enzyme activity was also observed in 5-d old calves (Hammon et al., 2003a). The activity of PEPCK in the cytosol and in mitochondria is similar in mature cattle (Taylor et al., 1971) despite a 10-fold greater abundance of PEPCK-C than PEPCK-M mRNA (Agca et al., 2002). In the present experiment, we examined total PEPCK activity and cytosolic PEPCK mRNA abundance. The lack of agreement between PEPCK-C mRNA and total PEPCK activity may represent a lack of specificity in assaying PEPCK activity. However, it is apparent that expression and activity of PC and PEPCK are differentially regulated in the developing calf, as has been noted previously in dairy cows during the transition to lactation (Greenfield et al., 2000).

Plasma growth hormone concentrations were elevated in CbST and CbSTDX on $\mathrm{d} 7$ and 14, but not on d 28 and 42 (Hammon et al., 2003b). Furthermore, bST treatment increased plasma cortisol on $d$ 7. Increased plasma cortisol in response to bST is consistent with observations that plasma cortisol is elevated in bSTtransgenic sheep that overexpress the growth hormone gene (Kadokawa et al., 2003). In the CbST, growth hormone did not alter plasma concentrations of glucose, insulin, or glucagon, and there was no effect of bST on PC and PEPCK mRNA or activity. These data corroborate in vitro measurements of gluconeogenesis from lactate and propionate on d 60 of life, demonstrating a lack of effect of bST on hepatic gluconeogenesis in young calves (Hammon and Donkin, 2002). Consistent with our data, administration of bST did not alter plasma glucose or insulin concentrations in neonatal calves (Hammon and Blum, 1998a). However, plasma insulin concentration was elevated in transgenic sheep over expressing growth hormone (Kadokawa et al., 2003). Studies on liver metabolism in lactating cows indicate enhanced gluconeogenic rate after bST treatment (Knapp et al., 1992) and lactating dairy cows given bST had greater PEPCK mRNA expression because of an increase in the rate of PEPCK transcription (Velez and Donkin, 2004). In contrast, exogenous growth hormone had no effect on PEPCK mRNA expression in growing rats (Donkin et al., 1996). Calves used in this study were responsive to bST, as hepatic glycogen content was reduced and growth performance enhanced with bST treatment (Hammon and Donkin, 2002), and the lack of change in plasma glucose concentration for the CbST might indicate elevated peripheral glucose utilization to support growth (Etherton and Bauman, 1998). Although it is evident that bST is active in milk-fed calves, the action of bST on gluconeogenesis and hepatic gene expression differs from that in the lactating dairy cow. A portion of the differences in response to bST between cows and calves may be a consequence of circulating concentrations and sensitivity to other hormones such as insulin.

The hyperglycemic effect of glucocorticoids is well established in cattle (McDowell, 1983; Brockman and Laarveld, 1986; Marciel et al., 2001), including veal calves (Sternbauer et al., 1998). We have found no increase in plasma glucose in CDX, but in CbSTDX, glucose concentration increased. Dexamethasone treatment increased plasma glucose concentrations in neonatal calves treated with DX immediately after birth (Hammon et al., 2003a). The increase in plasma glucose concentrations in CbSTDX was thought to be at least in part due to enhanced hepatic gluconeogenesis (McDowell, 1983; Kraus-Friedmann, 1984; Brockman and Laarveld, 1986). Furthermore, hepatic PEPCK and PC are known as rate-limiting enzymes for gluconeogenesis (Rognstad, 1979; Girard et al., 1992; Donkin, 1999), and their activities are stimulated by glucocorticoids (Kraus-Friedmann, 1984; Pilkis and Granner, 1992; Jitrapakdee and Wallace, 1999). Therefore, it was very surprising that expression and activities of PEPCK and PC were either unaffected or were even reduced in CDX and CbSTDX (except for activities of PEPCK on d 14). Our findings were supported by depression of PC mRNA levels and activities of PC and PEPCK after DX treatment in 5-d-old calves (Hammon et al., 2003a). Provided that PEPCK and PC activities are rate-limiting enzymes in this study and correspond with hepatic gluconeogenic activities, the elevated plasma glucose concen- 
trations in CbSTDX probably did not result from increased hepatic gluconeogenesis. We have not measured glucose production in liver of these calves, but findings in dairy cows support our assumption that glucocorticoid action on the hepatic gluconeogenic process are inconsistent (Drackley et al., 2001). Furthermore, DX, alone or in combination with bST, did not stimulate hepatic glycogen content, contrary to findings in lactating cows (McDowell, 1983).

Elevated plasma glucose concentrations in CbSTDX might be a result of reduced glucose utilization, which can be caused by bST and glucocorticoids (Amatruda et al., 1985; Lager, 1991), as was also shown in older cattle (McDowell, 1983; Etherton and Bauman, 1998; Sternbauer et al., 1998; Drackley et al., 2001). Alternatively, in rats treated with DX, intestinal glucose absorption was increased (Stojanovska et al., 1991); therefore, the elevated blood glucose concentration in CbSTDX might also be reflective of increased intestinal glucose absorption.

Treatment with DX decreased plasma cortisol concentration but increased plasma insulin levels, as expected (Hammon et al., 2003a). The rise in plasma insulin in CDX and CbSTDX and the lack of effect in CbST on plasma insulin indicates a synergistic effect of DX and bST in young calves. Both glucocorticoids and growth hormone reduce peripheral glucose utilization in humans because of the inhibition of insulin action (Lager, 1991; Møller et al., 1991), and this is also the case in older cattle (McDowell, 1983; Brockman and Laarveld, 1986; Etherton and Bauman, 1998). The effects of glucocorticoids and bST on insulin action, glucose metabolism, and PC and PEPCK expression as indicators of gluconeogenic capacity are less clear. Both growth hormone and glucocorticoids exert their stimulatory effects on hepatic glucose production at least in part through counteracting the hepatic response to insulin (Kahn et al., 1978; Lager, 1991). However, insulin is the more important hormone regulating gluconeogenesis than glucocorticoids (Goldstein et al., 1994), an observation that is supported by the dominant regulation of gluconeogenesis and hepatic PEPCK gene expression by insulin (Exton, 1979; Sasaki et al., 1984; Hanson and Patel, 1994). Provided that DX and bST treatment resulted in peripheral insulin resistance, it remains to be clarified whether insulin action in liver was also impaired by DX and/or bST treatment. Insulin resistance in the liver is characterized by increased mRNA expression and activities of PEPCK and PC and stimulation of gluconeogenesis (Hanson and Reshef, 1997; Jitrapakdee and Wallace, 1999). However, PEPCK and PC mRNA levels and PC activities were depressed in calves treated with DX or DX and bST. If we presume the development of insulin resistance in peripheral tissues in CDX and CbSTDX, a similar resistance does not appear to be fully manifested for the liver. Therefore, DX treatment affected insulin action differently in different tissues, an assumption also stated in neonatal calves (Hammon et al., 2003a).

It is unclear whether the reduced PEPCK and PC expression in CDX and CbSTDX may be a direct consequence of elevated plasma glucose concentrations. Plasma glucose concentrations were negatively associated with PEPCK and PC mRNA levels in the present study. In rats, glucose has been identified as a direct regulator of PEPCK mRNA expression (Cournarie et al., 1999), and a similar scenario for ruminants would partly explain a reduction in hepatic glucose production when plasma glucose is elevated (McDowell, 1983; Brockman and Laarveld, 1986; Hostettler-Allen et al., 1994). Evidence that glucose had directly inhibited PEPCK and PC mRNA levels could not be determined in the present study. The fact that inhibition of PEPCK and PC gene expression in CDX and CbSTDX were similar, but plasma glucose concentration only increased in CbSTDX, does not support a role for plasma glucose levels in regulating hepatic PEPCK and PC mRNA abundance.

In conclusion, the data indicate an age-dependent response of glucoregulatory hormones and of enzymes involved in hepatic gluconeogenesis to DX and to combined DX and bST treatment, but no response to bST alone. Dexamethasone and combined DX plus bST treatment influences the glucose status in young calves but does not stimulate expressions and activities of rate-limiting enzymes involved in gluconeogenesis, indicating that DX effects seem not to be associated with enhanced hepatic gluconeogenesis. The continuous exposure to DX and exposure to a sustained-release bST during the first $42 \mathrm{~d}$ of life indicate that the effects of $\mathrm{bST}$ require the addition of DX. Length of exposure and calf age are confounded in the present data. Therefore, additional experiments are necessary to determine the effects of duration and timing of exposure relative to birth on hepatic gene expression.

\section{ACKNOWLEDGMENTS}

Many thanks to Mike Grott and his team at the Purdue Dairy Research and Education Centre for daily calf care. Thanks to Juan Carlos Velez, Stacy Crowder, and Jon Townsend for assistance with liver biopsy sampling and Tracy Wiegand for technical assistance with metabolite assays. This work was supported in part by funds from the Indiana Agricultural Research as part of the North Central Regional project NC-1009. Harald M. Hammon was supported by the University of Berne during his residence at Purdue University. 


\section{REFERENCES}

Agca, C., R. B. Greenfield, J. R. Hartwell, and S. S. Donkin. 2002. Cloning and characterization of bovine cytosolic and mitochondrial PEPCK during transition to lactation. Physiol. Genomics 11:53-63.

Amatruda, J. M., J. N. Livingston, and D. H. Lockwood. 1985. Cellular mechanisms in selected states of insulin resistance: Human obesity, glucocorticoid excess, and chronic renal failure. Diabetes Metab. Rev. 1:293-317.

Atkin, B. M., M. F. Utter, and M. B. Weinberg. 1979. Pyruvate carboxylase and phosphoenolpyruvate carboxykinase activity in leukocytes and fibroblasts from a patient with pyruvate carboxylase deficiency. Pediatr. Res. 13:38-53.

Ballard, F. J., and R. W. Hanson. 1967. Phosphoenolpyruvate carboxykinase and pyruvate carboxylase in developing rat liver. Biochem. J. 104:866-871.

Breier, B. H., M. H. Oliver, and B. W. Gallaher. 2000. Regulation of growth and metabolism during postnatal development. Pages 187-204 in Ruminant Physiology: Digestion, Metabolism, Growth and Reproduction. P. B. Cronjé, ed. CABI Publishing, New York, NY.

Brockman, R. P., and B. Laarveld. 1986. Hormonal regulation of metabolism in ruminants; A review. Livest. Prod. Sci. 14:313-334.

Cournarie, F., D. Azzout-Marniche, M. Foretz, C. Guichard, P. Ferre, and F. Foufelle. 1999. The inhibitory effect of glucose on phosphoenolpyruvate carboxykinase gene expression in cultured hepatocytes is transcriptional and requires glucose metabolism. FEBS Lett. 460:527-532.

Drackley, J. K., T. R. Overton, and G. N. Douglas. 2001. Adaptations of glucose and long-chain fatty acid metabolism in liver of dairy cows during the periparturient period. J. Dairy Sci. 84 (E. Suppl.): E100-E112.

Donkin, S. S. 1999. Role of the endocrine pancreas in animal metabolism, growth and performance. Pages 315-328 in Biology of the Pancreas in Growing Animals. S. G. Pierynowski and R. Zabielski, ed. Elsevier, Amsterdam, The Netherlands.

Donkin, S. S., and L. E. Armentano. 1995. Insulin and glucagon regulation of gluconeogenesis in preruminating and ruminating bovine. J. Anim. Sci. 73:546-551.

Donkin, S. S., A. D. McNall, B. S. Swencki, J. L. Peters, and T. D. Etherton. 1996. The growth hormone dependent decrease in hepatic fatty acid synthase mRNA is the result of a decrease in gene transcription. J. Mol. Endocrinol. 16:151-158.

Etherton, T. D., and D. E. Bauman. 1998. Biology of somatotropin in growth and lactation of domestic animals. Physiol. Rev. 78:745-761.

Exton, J. H. 1979. Regulation of gluconeogenesis by glucocorticoids. Monogr. Endocrinol. 12:535-546.

Filsell, O. H., I. G. Jarrett, P. H. Taylor, and D. B. Keech. 1969. Effects of fasting, diabetes and glucocorticoids on gluconeogenic enzymes in the sheep. Biochim. Biophys. Acta 184:54-63.

Fowden, A. L. 1997. Comparative aspects of fetal carbohydrate metabolism. Equine Vet. J. Suppl. 24:19-25.

Girard, J., P. Ferré, J. P. Pégorier, and P. H. Duée. 1992. Adaptions of glucose and fatty acid metabolism during perinatal period and suckling-weaning transition. Physiol. Rev. 72:507-562.

Goldstein, R. E., A. D. Cherrington, G. W. Reed, D. B. Lacy, D. H. Wasserman, and N. N. Abumrad. 1994. Effects of chronic hypercortisolemia on carbohydrate metabolism during insulin deficiency. Am. J. Physiol. 266:E618-E627.

Greenfield, R. B., M. J. Cecava, and S. S. Donkin. 2000. Changes in mRNA expression for gluconeogenic enzymes in liver of dairy cattle during the transition to lactation. J. Dairy Sci. 83:12281236.

Hammon, H. M., and J. W. Blum. 1998a. Endocrine and metabolic changes in neonatal calves in response to growth hormone and long- $\mathrm{R}^{3}$-insulin-like growth factor-I administration. Biol. Neonate 73:121-128.

Hammon, H., and J. W. Blum. 1998b. Metabolic and endocrine traits of neonatal calves are influenced by feeding colostrum for different durations or only milk replacer. J. Nutr. 128:624-632.
Hammon, H. M., and S. S. Donkin. 2002. Growth hormone influences growth performance, but does not affect gluconeogenesis from lactate or propionate in 60-d old veal calves. J. Anim. Sci. 80(Suppl. 1): 337. (Abstr.)

Hammon, H. M., S. N. Sauter, M. Reist, Y. Zbinden, C. Philipona, C. Morel, and J. W. Blum. 2003a. Dexamethasone and colostrum feeding differently affect hepatic gluconeogenic enzymes in neonatal calves. J. Anim. Sci. 81:3095-3106.

Hammon, H. M., Y. Zbinden, H. Sauerwein, B. H. Breier, J. W. Blum, and S. S. Donkin. 2003b. The response of the hepatic insulin-like growth factor system to growth hormone and dexamethasone in calves. J. Endocrinol. 179:427-435

Hanson, R. W., and Y. M. Patel. 1994. Phosphoenolpyruvate carboxykinase (GTP): The gene and the enzyme. Adv. Enzymol. Relat. Areas Mol. Biol. 69:203-281.

Hanson, R. W., and L. Reshef. 1997. Regulation of phosphoenolpyruvate carboxykinase (GTP) gene expression. Annu. Rev. Biochem. 66:581-611.

Hostettler-Allen, R. L., L. Tappy, and J. W. Blum. 1994. Insulin resistance, hyperglycemia, and glucosuria in intensively milk-fed calves. J. Anim. Sci. 72:160-173.

Jitrapakdee, S., and J. W. Wallace. 1999. Structure, function and regulation of pyruvate carboxylase. Biochem. J. 340:1-16.

Kadokawa, H., J. R. Briegel, M. A. Blackberry, D. Blache, G. B. Martin, and N. R. Adams. 2003. Relationships between plasma concentrations of leptin and other metabolic hormones in GHtransgenic sheep infused with glucose. Domest. Anim. Endocrinol. 24:219-229.

Kahn, C. R., I. D. Goldfine, D. M. Neville, Jr., and P. De Meyts. 1978. Alterations in insulin binding induced by changes in vivo in the levels of glucocorticoids and growth hormone. Endocrinology 103:1054-1066.

Knapp, J. R., H. C. Freetly, B. L. Reis, C. C. Calvet, and R. L. Baldwin. 1992. Effects of somatotropin and substrates on patterns of liver metabolism in lactating dairy cows. J. Dairy Sci. 75:1025-1035.

Kraus-Friedmann, N. 1984. Hormonal regulation of hepatic gluconeogenesis. Physiol. Rev. 64:170-259.

Lager, I. 1991. The insulin-antagonistic effect of the counterregulatory hormones. J. Intern. Med. Suppl. 229:41-47.

Liggins, G. C. 1994. The role of cortisol in preparing the fetus for birth. Reprod. Fertil. Dev. 6:141-150.

Marciel, S. M., C. S. Chamberlain, R. P. Wettemann, and L. J. Spicer. 2001. Dexamethasone influences endocrine and ovarian function in dairy cattle. J. Dairy Sci. 84:1998-2009.

McDowell, G. H. 1983. Hormonal control of glucose homoeostasis in ruminants. Proc. Nutr. Soc. 42:149-167.

Møller, N., J. O. L. Jørgensen, N. Abildgård, L. Ørskov, O. Schmitz, and J. S. Christiansen. 1991. Effects of growth hormone on glucose metabolism. Horm. Res. 36(Suppl.):32-35.

Pilkis, S. J., and D. K. Granner. 1992. Molecular physiology of the regulation of hepatic gluconeogenesis and glycolysis. Annu. Rev. Physiol. 54:885-909.

Prior, R. L., and R. A. Scott. 1977. Ontogeny of gluconeogenesis in the bovine fetus: Influence of maternal dietary energy. Dev. Biol. 58:384-393.

Roehrig, K. L., and J. B. Allred. 1974. Direct enzymatic procedure for the determination of liver glycogen. Anal. Biochem. 58:414-421.

Rognstad, R. 1979. Rate-limiting steps in metabolic pathways. J. Biol. Chem. 254:1875-1878.

SAS User's Guide: Statistics, Version 6.11 Edition. 1995. SAS Inst., Inst., Cary, NC.

Sasaki, K., T. P. Cripe, S. R. Koch, T. L. Andreone, D. D. Petersen, E. G. Beale, and D. K. Granner. 1984. Multihormonal regulation of phosphoenolpyruvate carboxykinase gene transcription. The dominant role of insulin. J. Biol. Chem. 259:15242-15251.

Sternbauer, K., J. Luthman, and S. O. Jacobsson. 1998. Flumethasone-induced insulin resistance in calves. J. Vet. Med. A 45:441-443.

Stojanovska, L., G. Rosella, and J. Proietto. 1991. Dexamethasoneinduced increase in the rate of appearance in plasma of gutderived glucose following an oral glucose load in rats. Metabolism 40:297-301. 
Taylor, P. H., J. C. Wallace, and D. B. Keech. 1971. Gluconeogenic enzymes in sheep. Biochem. Biophys. Acta 237:179-191.

Velez, J. C., and S. S. Donkin. 2004. Bovine somatotropin increases hepatic phosphoenolpyruvate carboxykinase mRNA in lactating dairy cows. J. Dairy Sci. 87:1325-1335.

Wajchenberg, B. L., C. F. Prestes, H. Okada, T. D. Torres, A. C. Lerario, V. C. Borghi, D. A. Malerbi, F. A. Giurna, B. Liberman, and D. Gianella. 1984. Glucocorticoids, glucose metabolism and hypothalamic-pituitary-adrenal axis. Adv. Exp. Med. Biol. 171:25-44.

Wallace, J. C. 1984. Distribution and biological functions of pyruvate carboxylase in nature. Pages 5-63 in Pyruvate Carboxylase. D. B. Keech and J. C. Wallace, ed. CRC Series in Enzyme Biology, CRC Press, Boca Raton, FL. 